\title{
The Modulation Effect of Triglyceride Type and Phospholipids Type w-3 LCPUFA on Mice Gut Microbiota
}

\author{
X. Wang, F. Liu, Y. M. Wang, C. H. Xue, Q. J. Tang* \\ College of Food Science and Engineering, Ocean University of China, Qingdao, China \\ Email: *tangqingjuan@ouc.edu.cn
}

How to cite this paper: Wang, X., Liu, F., Wang, Y.M., Xue, C.H. and Tang, Q.J. (2017) The Modulation Effect of Triglyceride Type and Phospholipids Type $\omega-3$ LCPUFA on Mice Gut Microbiota. Journal of Biosciences and Medicines, 5, 54-64. https://doi.org/10.4236/jbm.2017.59006

Received: July 21, 2017

Accepted: September 3, 2017

Published: September 6, 2017

Copyright $\odot 2017$ by authors and Scientific Research Publishing Inc. This work is licensed under the Creative Commons Attribution International License (CC BY 4.0).

http://creativecommons.org/licenses/by/4.0/ (c) (i) Open Access

\begin{abstract}
The evaluation from prospective cohort studies on the dietary $\omega$-3 long-chain polyunsaturated fatty acid (LCPUFA) supplementation and nutritional value is consistent. However, the effect of different types of $\omega-3$ long-chain PUFA ( $\omega-3$ LCPUFA) on microbiota in intestine is inconsistent. In this study, the mice were divided into three groups (N, PL, FO), with AIN-93M (N), AIN-93M + Phospholipids type $\omega$-3 LCPUFA (PL) and AIN-93M + triglyceride type $\omega-3$ LCPUFA (FO), respectively. Denaturing Gradient Gel Electrophoresis (DGGE) was used to detect the structure of intestinal microbiota. The data showed that the composition of gut microbiota was changed by treating with the two types of $\omega-3$ LCPUFA. The results revealed that gut microbiota' enrichment in FO group was decreased while in PL group was increased. The data also showed that the histological morphology of the small intestine in treated mice was improved especially in group PL, which was much more significant and suggested that Phospholipids type $\omega-3$ LCPUFA is beneficial to intestinal health.
\end{abstract}

\section{Keywords}

Phospholipids Type $\omega-3$ LCPUFA, Triglyceride Type $\omega-3$ LCPUFA, Gut Microbiota

\section{Introduction}

A healthy body has been attributed to omega-3 long chain polyunsaturated fatty acids ( $\omega$-3 LCPUFA) due to LCPUFAs, such as eicosapentaenoic acid (EPA) and docosahexaenoic acid (DHA), which have been associated with several physiological functions: reducing oxidative stress [1], preventing allergic and cardi- 
ovascular disease [2], playing an important role in inflammatory processes and resolution [3] [4]. Now, there are several types of $\omega$-3 LCPUFA products, involving free fatty acid (FFA), ethyl ester (EE), triglyceride (TG), phospholipids (PL). Because FFA and EE have special properties, this makes them susceptible to oxidative rancidity and difficult to digest. However, as for TG and PL, they are common in nature and can easily be absorbed through the gastrointestinal tract and do not cause any harm to human body. According to [5], PL has the superiority to reduce adipose tissue inflammation than TG. Nowadays, researchers are focusing on the possibility, while the mechanism is not understood clearly.

A large body of studies had revealed that human's microbiome is composed of our own genome [6]. Microbial community is the most densely colonized and diverse in human gut [7]. Therefore, the changes of gut microbiota can affect metabolic properties and host physiology [8] [9]. As we all know, host diet maybe the main reason to change the gut microbial composition [10]. So many studies have paid attention to explain the effects of dietary carbohydrates and dietary protein on gut microbiota. But few studies had investigated the effects of dietary lipids on human intestinal microbiota. According to some studies, dietary lipids are mostly absorbed in the small intestine, but a recent research showed that $7 \%$ of ${ }^{13} \mathrm{C}$ labeled dietary fatty acids were excreted in stool [11], which indicated that intestinal flora and dietary fat can interact between each other. But the effects on microbiota caused by $\omega-3$ LCPUFA and the differences caused by triglyceride type $\omega$-3 LCPUFA and phospholipids type $\omega-3$ LCPUFA are not clear. In this study, to detect microbiota composition, DGGE was used and hoped to find whether intestinal flora is different among the three experiment groups (N FO and PL), which concluded the advantages of phospholipids type $\omega$-3 LCPUFA over triglyceride type $\omega$-3 LCPUFA. It will provide a strong theoretical basis for utilizing and explaining the functions of $\omega-3$ LCPUFA.

\section{Materials and Methods}

\subsection{Materials}

The triglyceride type $\omega-3$ LCPUFA (fish oil, DHA + EPA 50\%) was purchased from Sinomega Biotech Engineering Co. Ltd (Zhoushan, Zhejiang, China). Phospholipids type $\omega-3$ LCPUFA (DHA + EPA 40\%) was extracted from the squid (Sthenoteuthis oualaniensis) eggs which were provided by Zhoushan fishing companies (China). The detail component was described in supplementary table S1.

All the reagents used in this study were analytical purity.

\subsection{Animals and Treatment}

Thirty male Balb/c mice (18 - $20 \mathrm{~g}$, 4 weeks old) were obtained from Vital River Laboratory Animal Technology Co., Ltd. (Beijing, China). During the feeding, all mice were housed in a room, which maintained under a 12 hours light/dark 
cycle at $24^{\circ} \mathrm{C}$. Mice were access to get clean water and maintenance purified diet, which is based on AIN-93 M. Before the intervention, we carried out the group respectively: Normal control group (N), Triglyceride type $\omega-3$ LCPUFA group (FO), Phospholipids type $\omega-3$ LCPUFA group (PL). The total DHA + EPA content of FO group and PL group was consistent, as well as EPA/DHA. The detail ingredient in the diet was described in Supplementary (Table S2). The mice were sacrificed through cervical dislocation on the $30^{\text {th }}$ day and small intestines were collected then kept in $-80^{\circ} \mathrm{C}$ for future analysis. All experimental procedures were conducted according to the guidelines provided by the ethical committee of experimental animal care at Ocean University of China (Qingdao city, Shandong province, China).

\subsection{Faecal Bacteria Collection and Bacterial Genomic DNA Extraction}

In order to find the effect of dietary LCPUFA on gut microbiota, faecal samples were separately collected in the sterile environment. Bacterial genomic DNA was extracted from the faecal samples with the QIAamp DNA stool kit (Qiagen, MD, USA), based on the manufacturer's instructions.

\subsection{DGGE Analysis}

\subsubsection{PCR Amplification of Bacterial 16S rDNA Fragment}

To find the differences of gut microbiota in the three groups, the V3 region of the 16S rRNA gene was amplified by PCR, which using the universal bacterial primers $338 \mathrm{~F}$ (5'-CCTACGGGAGGCAG-CAG-3') and 518R (5'-ATTAC-CG CGGCTGCTGG-3'), a 41-bpGCclamp (CGCCCGGGGCGCGCCCCGGGGCGGGGCGGGGGCGCGGGGGG) was incorporated into the 5 ' end of $338 \mathrm{~F}$. The PCR amplification was carried out in a MJ Mini Personal Thermal Cycler (BIO-RAD, America). Each reaction was performed in a total volume of $50 \mu \mathrm{L}$ containing DNA template $100 \mathrm{ng}, 10 \times$ PCR buffer $5 \mu \mathrm{L}$, dNTP mix $(10 \mathrm{mM}) 3.2$ $\mu \mathrm{L}, \mathrm{MgCl}_{2}(25 \mathrm{mM}) 3 \mu \mathrm{L}$, each primer $(20 \mathrm{mM}) 0.5 \mu \mathrm{L}$, and $5 \mathrm{U} / \mu \mathrm{L}$ of Taq DNA polymerase (Takara, Japan) $1 \mu \mathrm{L}$. The PCR conditions were as follows: $95^{\circ} \mathrm{C}$ for $5 \mathrm{~min}$, followed by 30 cycles of $94^{\circ} \mathrm{C}$ for $1 \mathrm{~min}, 55^{\circ} \mathrm{C}$ for $45 \mathrm{~s}$, and $72^{\circ} \mathrm{C}$ for 1 min, and a final extension at $72^{\circ} \mathrm{C}$ for $10 \mathrm{~min}$. PCR products were recycled with DNA Gel Extraction Kit (Omega, USA).

\subsubsection{Denaturing Gradient Gel Electrophoresis (DGGE) of PCR Products} The total volume $10 \mu \mathrm{L}$ PCR products were used to DGGE analysis. The concentration of polyacrylamide gel was $7 \%$, denaturing gradient was $35 \%-55 \%$. Polyacrylamide gel was electrophoresed for 5 hours in $1 \mathrm{x}$ scavenged buffer (under $\left.60^{\circ} \mathrm{C}, 150 \mathrm{v}\right)$.

\subsubsection{The Sequencing and Recycling of Dominant Banding in DGGE HapMap}

The dominant banding was recycled with Poly-Gel DNA Extraction Kit (Omega, USA). $2 \mu \mathrm{L}$ recycled product as the template, the primer was shown as 2.4.1.PCR 
amplification system $(50 \mu \mathrm{L}): 10 \times$ PCR buffer $5 \mu \mathrm{L}$; dNTP $(2.5 \mathrm{mM}) 3.2 \mu \mathrm{L}$; rTaq $(5 \mathrm{U} / \mu \mathrm{L}) 0.4 \mu \mathrm{L} ; 338 \mathrm{~F}(20 \mathrm{mM}) 1 \mu \mathrm{L} ; 518 \mathrm{R}(20 \mathrm{mM}) 1 \mu \mathrm{L}$; template DNA $1 \mu \mathrm{L}$; added $\mathrm{ddH}_{2} \mathrm{O}$ to $50 \mu \mathrm{L}$. The PCR conditions were as follows: $94^{\circ} \mathrm{C}$ for $4 \mathrm{~min}$, followed by 30 cycles of $94^{\circ} \mathrm{C}$ for $30 \mathrm{~s}, 55^{\circ} \mathrm{C}$ for $30 \mathrm{~s}$, and $72^{\circ} \mathrm{C}$ for $30 \mathrm{~s}$, and a final extension at $72^{\circ} \mathrm{C}$ for $10 \mathrm{~min}$. We recycled the amplified DNA fragments, connected to pMD18-T vector, conveyed to $\mathrm{DH}_{5}-\alpha$ cells, screened positive clones and sequenced. Principal component analysis (PCA) and cluster analysis were employed to compare the gut microbiota composition among groups. Important bands were retrieved, sequenced (Sangon Biotech Co. Ltd., Shanghai, China) and identified in Genbank.

\subsection{Real-Time Quantitative Polymerase Chain Reaction (Real-Time PCR)}

Real-time PCR was performed in the iCycler iQ5 system (Bio-Rad Laboratories Inc., California, USA). A reaction volume of $25 \mu \mathrm{L}$ was used for the quantitative real-time PCR assay which consisted of $12.5 \mu \mathrm{L}$ Maxima SYBR Green qPCR Master mix (F. Hoffman-La Roche, Ltd., Basel, Switzerland), $10 \mu \mathrm{M}$ primers (0.3 $\mu \mathrm{L}$ each of forward and reverse primer), $5.9 \mu \mathrm{L}$ nuclease-free water, and $6 \mu \mathrm{L}$ template. The thermal conditions consisted of an initial enzyme activation at $95^{\circ} \mathrm{C}$ for $10 \mathrm{~min}$ followed by $30-35$ cycles of denaturation at $95^{\circ} \mathrm{C}$ for $15 \mathrm{~s}$, annealing at $60^{\circ} \mathrm{C}$ for $20 \mathrm{~s}$ and extension at $72^{\circ} \mathrm{C}$ for $30 \mathrm{~s}$. The number of DNA molecules was counted then we calculate gene expression level through the standard curve method. The sequences of primers used in this study are described in Supplementary Table S3.

\subsection{Histological Study of the Intestine}

After sacrificed the mice, we obtained small intestinal samples. In order to study the morphological structure of the intestinal tissues, the samples were put in $10 \%$ formalin for 24 hours and washed with water, then used gradient concentrations of alcohol to remove the water, and then put samples in paraffin. The sections, which is $5 \mu \mathrm{m}$ thickness were obtained then dyed with haematoxylin and eosin, and then we used light microscopy (Olympus BX-41: Olympus Optical Co. Ltd, Tokyo, Japan) to observe the histological changes, such as morphological structure, oedema, and haemorrhage. The villus length divides the crypt depth (V/C ratio) of the small intestine were measured by a digital image analysis system, Image pro plus software (Olympus Optical Co. Ltd, Tokyo, Japan).

\subsection{Statistical Analysis}

All values in the tables and figures are expressed as mean \pm standard error (SE) of the mean. Statistical comparisons of the results were performed using Tukey's post-hoc test following analysis of variance (ANOVA) by SPSS 18.0. $P<0.05$ was considered statistically significant. 


\section{Result}

\subsection{Structure Changes in Gut Microbiota Induced by Triglyceride Type $\omega-3$ LCPUFA and Phospholipids Type $\omega$-3 LCPUFA}

To test the structure of the gut microbiota, DGGE was be used. According to the $16 \mathrm{~S}$ rRNA V3 region PCR-DGGE patterns, the overall composition of the normal treatment showed some differences in gray value from the FO and PL group (Figure 1(a)). Compared with the normal group, the number of bands and the intensities of bands in PL group were increased significantly. But in FO group the number of bands was decreased, while the intensities of bands were increased. So we can conclude that the diversity and structure of the gut microbiota in FO and PL group were changed after treatment. More details were also clearly shown in the virtual figure (Figure 1(b)) of PCR-DGGE fingerprints. Common microbial a diversity indices, such as richness, evenness, and Shannon indices (Table 1) were evaluated. The data suggested that different types of $\omega-3$ LCPUFA in Balb/c mice appeared to affect microbial diversity in the colon microbiome. For example, species enrichment was different among the three

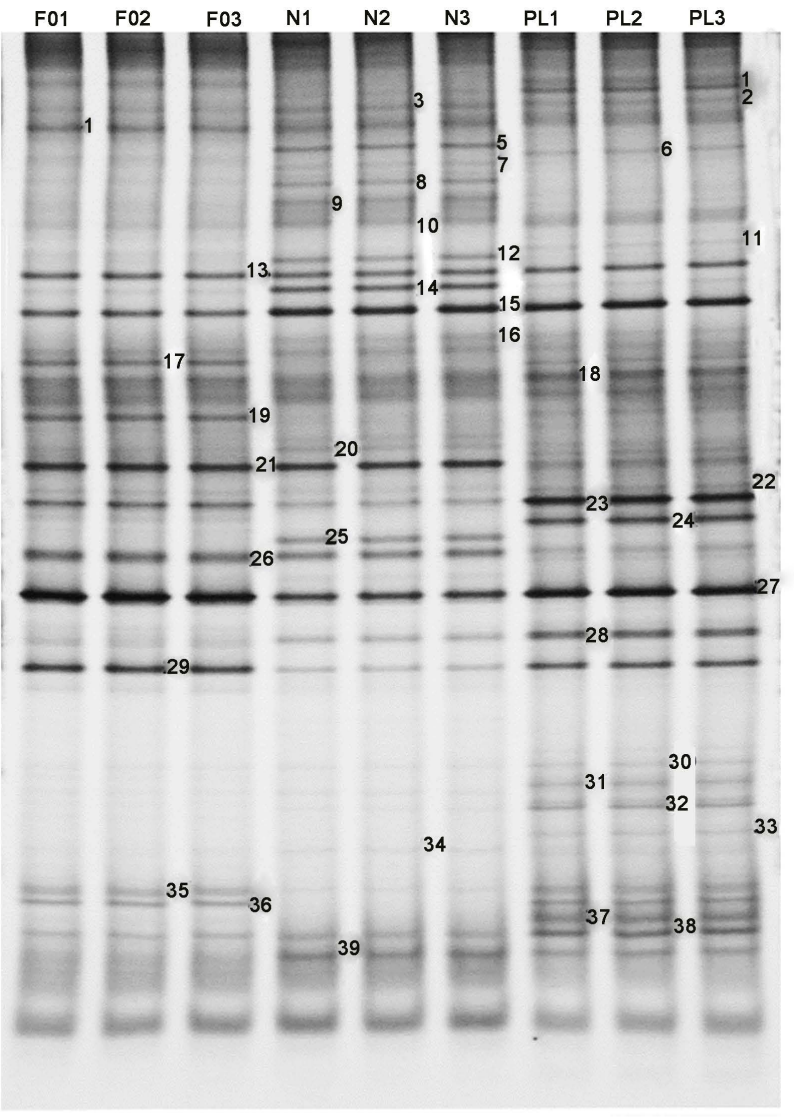

(a)

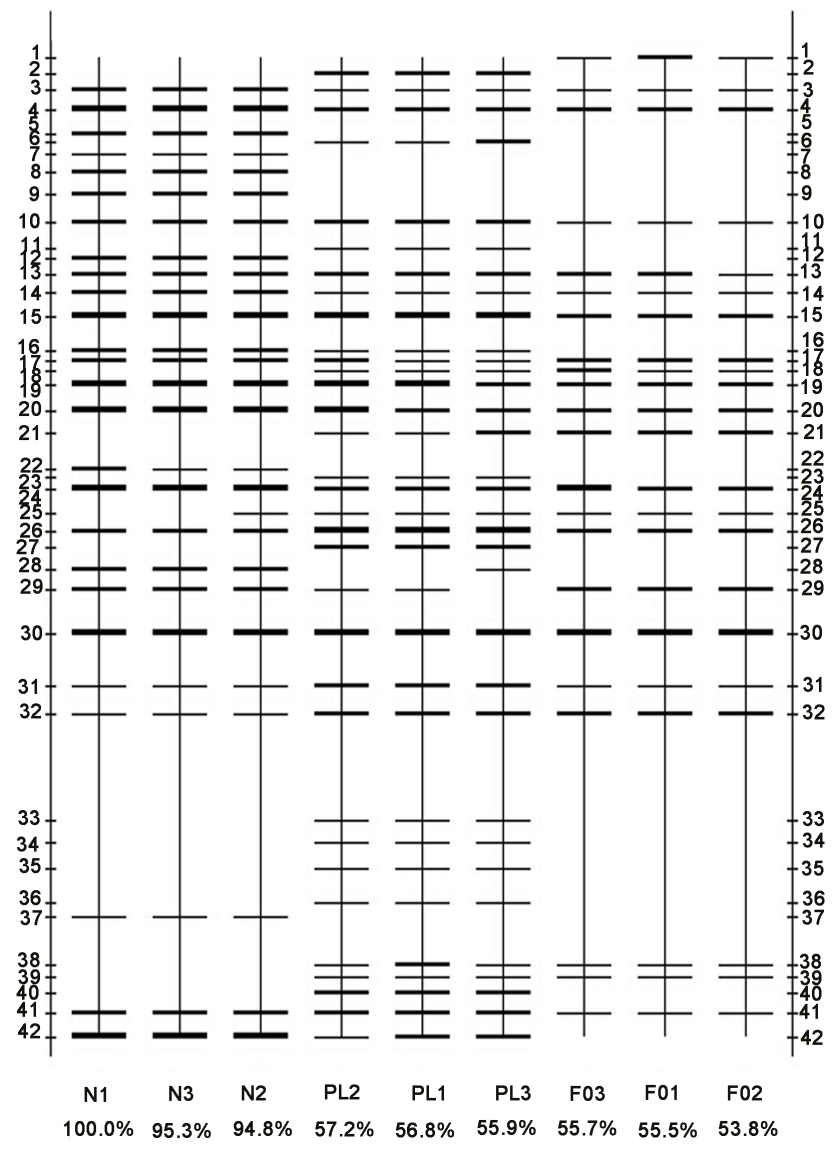

(b)

Figure 1. Comparison of gut microbiota composition between the mouse groups. (a) Denaturing gradient gel electrophoresis (DGGE) fingerprinting of V3 region of 16S rRNA genes from faecal bacterial communities; (b) The virtual map of DGGE electrophoresis. Every sample included feces of ten mice and feces in 1, 2 and 3 were same ten ones. 
Table 1. Analysis of the microbiota diversity of mice intestine.

\begin{tabular}{cccc}
\hline Group & Shannon-wiener $(H)$ & Evenness $(E)$ & Richness $(S)$ \\
\hline N & $3.2533 \pm 0.0321$ & $0.9667 \pm 0.0058$ & $29.0000 \pm 1.0000$ \\
FO & $3.0833 \pm 0.0577$ & $0.9633 \pm 0.0058$ & $24.6667 \pm 1.1547^{\mathrm{ab}}$ \\
PL & $3.4567 \pm 0.0321$ & $0.9700 \pm 0.0008$ & $35.3333 \pm 1.1527^{\mathrm{a}}$ \\
\hline
\end{tabular}

experiment groups. The flora diversity in group FO decreased but in PL treatment group the diversity was increased. Then SPSS was used to conduct Principal component analysis (PCA) (Figure 2(a)) and the cluster dendrogram (Figure 2(b)) were also estimated. According to the data, we can found that the mice groups were made into three clusters, with first principal component (PC1) accounting for $63.6 \%$ of the variation. The results showed a distinct difference in the three groups, which could be confirmed that $\omega-3$ LCPUFA caused the significant change of gut microbiota.

\subsection{The Sequencing of the Significantly Different Bands in DGGE Fingerprints}

To find the differences between the bands, 17 bands were selected to sequencing, and the data was shown in Table 2. Combined with (Figure 1(b)), we can found that there were 4 significant bands in the normal group compared with other two groups: 5 (Clostridiales bacterium), 8 (Bacteroides acidifaciens), 9 (Alistipes timonensis JC136), 25 (Clostridiales bacterium). But 17 (Lactobacillus animalis), 23 (Akkermansia muciniphila), 24 (Ruminococcus), 27 (Lactococcus lactis) were more clear in PL group and FO group than normal group and the bands of 23, 27 were superior in PL than FO group. While the 21 band (Streptococcus thermophilus) in PL group was inferior than the other two groups. The relative abundance of these bacteria was analyzed by gray intensity in Figure 1(a), which was depicted in (Figure 3(a)). The abundance of Firmicutes was showed in results, which increased after administrated with $\omega-3$ LCPUFA. Firmicutes are often highly represented in the gut microbiota of healthy individuals and can be reduced in illness [12]. We demonstrated the effect of triglyceride and phospholipids type $\omega$-3 LCPUFA on the bands of 17, 23, 27, 29 with RT-PCR, the results were shown in (Figures 3(b)-(d)). According to the results we can found that the two types of $\omega-3$ LCPUFA helped improving the microbial structure.

\subsection{Triglyceride Type $\omega-3$ LCPUFA and Phospholipids Type $\omega-3$ LCPUFA Improves the Histological Morphology of the Small Intestine in Treated Mice}

To verify the activities of the two types $\omega$-3 LCPUFA, we analysed the histological morphology of the small intestines of the mice in this study, the data were showed in Figure 4. Results showed that the morphology of the small intestine was intact in the three groups of mice. As observed, the structures of the 
Table 2. The analysis results of DGGE gel bands recovery sequence.

\begin{tabular}{|c|c|c|c|c|}
\hline $\begin{array}{l}\text { Band } \\
\text { Number }\end{array}$ & Similar strain & $\begin{array}{l}\text { Accession } \\
\text { number }\end{array}$ & Similarity & Classification \\
\hline Band 5 & Clostridiales bacterium & AB702938 & 99 & Firmicutes clostridiales \\
\hline Band 6 & Lactococcus raffinolactis & KJ561012 & 100 & Firmicutes lactococcus \\
\hline Band 8 & Bacteroides acidifaciens & NR_112931 & 99 & Bacteroidetes bacteroides \\
\hline Band 9 & Alistipes timonensis JC136 & NR_125589 & 98 & Bacteroidetes alistipes \\
\hline Band 12 & $\begin{array}{l}\text { Uncultured Bacteroidales } \\
\text { bacterium }\end{array}$ & AB702775 & 100 & $\begin{array}{l}\text { Bacteroidetes } \\
\text { bacteroidales }\end{array}$ \\
\hline Band 14 & Uncultured bacterium & HQ321625 & 99 & $\begin{array}{l}\text { Bacteria; environmental } \\
\text { samples }\end{array}$ \\
\hline Band 17 & Lactobacillus animalis & AB911535 & 100 & Firmicutes lactobacillus \\
\hline Band 19 & Uncultured bacterium & AB470808 & 100 & $\begin{array}{l}\text { Bacteria; } \\
\text { environmental samples }\end{array}$ \\
\hline Band 21 & $\begin{array}{l}\text { Streptococcus } \\
\text { thermophilus }\end{array}$ & LC004488 & 99 & Firmicutes streptococcus \\
\hline Band 23 & $\begin{array}{l}\text { Akkermansia } \\
\text { muciniphila }\end{array}$ & NR_074436 & 99 & $\begin{array}{l}\text { Verrucomicrobia } \\
\text { akkermansia }\end{array}$ \\
\hline Band 24 & [Ruminococcus] gnavus & AB910745 & 100 & Firmicutes blautia \\
\hline Band 25 & Clostridiales bacterium & AB702931 & 100 & Firmicutes clostridiales \\
\hline Band 27 & Lactococcus lactis & KP213178 & 100 & Firmicutes lactococcus \\
\hline Band 28 & [Clostridium] innocuum & HE974931 & 99 & $\begin{array}{l}\text { Firmicutes } \\
\text { Erysipelatoclostridium }\end{array}$ \\
\hline Band 29 & Lactococcus lactis & KP720567 & 99 & Firmicutes lactococcus \\
\hline Band 35 & Uncultured bacterium & JQ894308 & 100 & $\begin{array}{l}\text { Bacteria; environmental } \\
\text { samples }\end{array}$ \\
\hline Band 36 & $\begin{array}{l}\text { Uncultured Bacteroidales } \\
\text { bacterium }\end{array}$ & AB702739 & 100 & $\begin{array}{l}\text { Bacteroidetes } \\
\text { bacteroidales }\end{array}$ \\
\hline
\end{tabular}

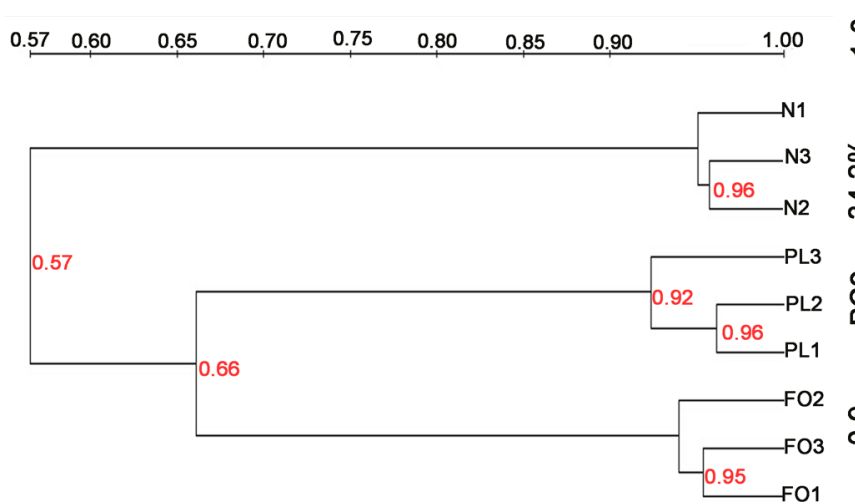

(a)

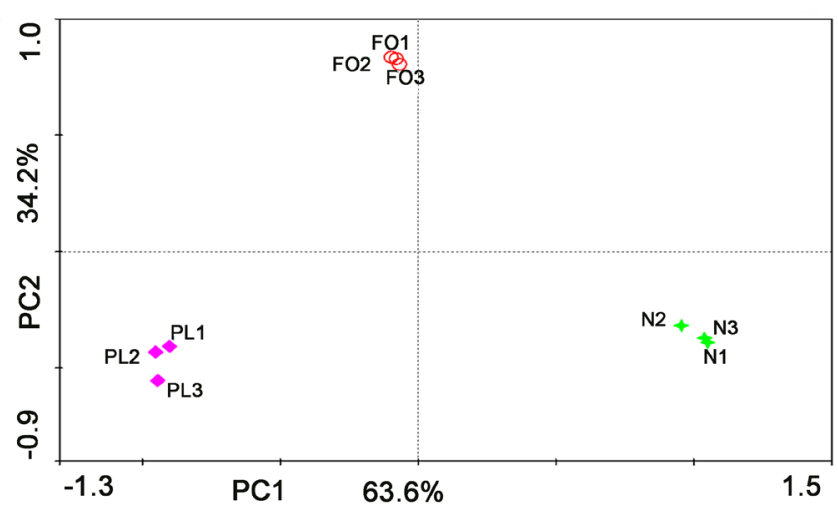

(b)

Figure 2. PCA and cluster analysis of DGGE fingerprint. (a) The principal components analysis (PCA) scores plot according to the DGGE fingerprint; (b) Clustering of gut microbiota based on distances between different groups. 


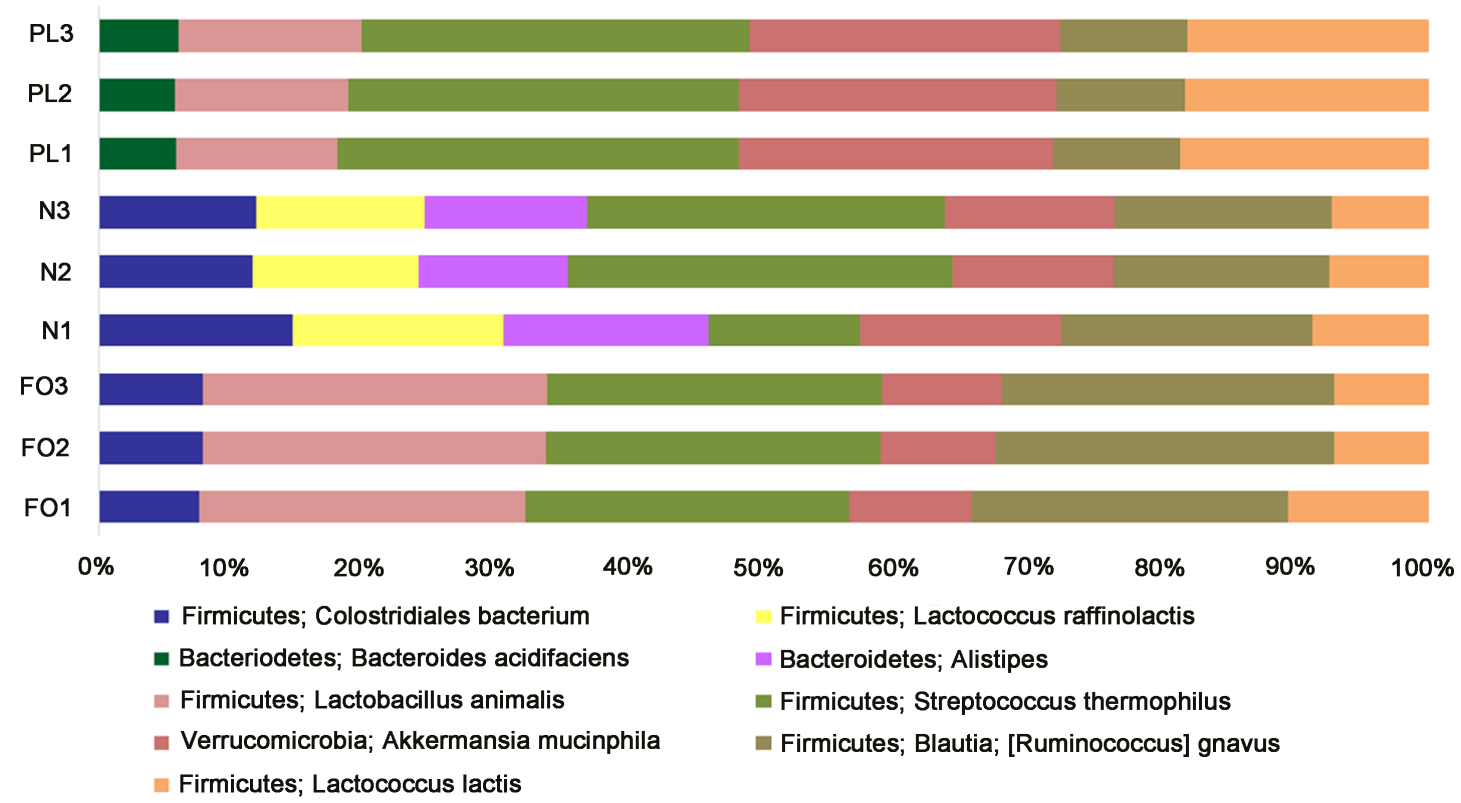

(a)

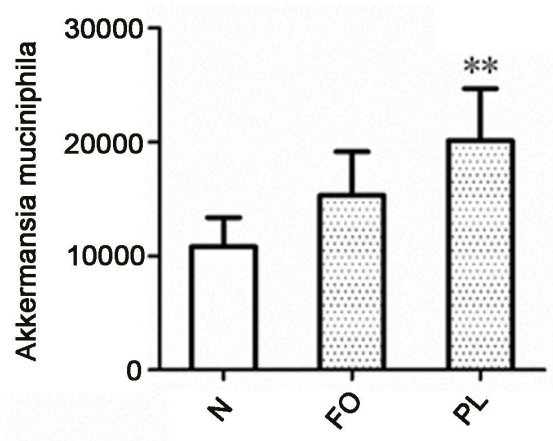

(b)

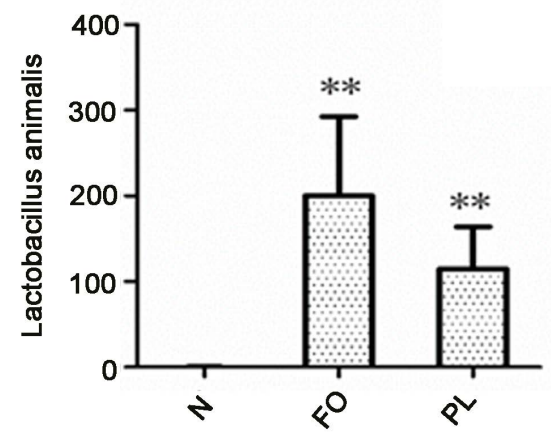

(c)

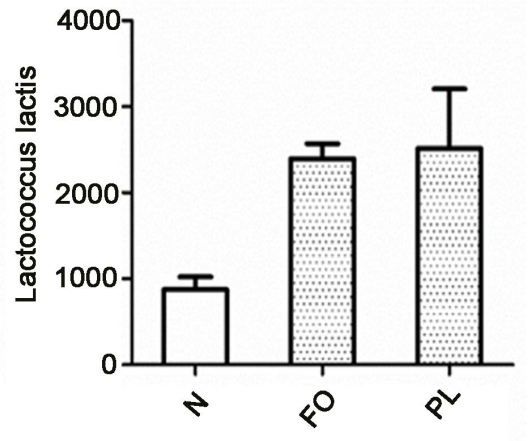

(d)

Figure 3. The relative abundance of bacteria analyzed by gray intensity and RT-PCR. (a) The relative abundance of bacteria analyzed by gray intensity; (b) The quantity of Akkeermansia muciniphila analyzed by RT-PCR; (c) The quantity of Lactobacillus analyzed by RT-PCR; (d) The quantity of Lactococcus lactis analyzed by RT-PCR.
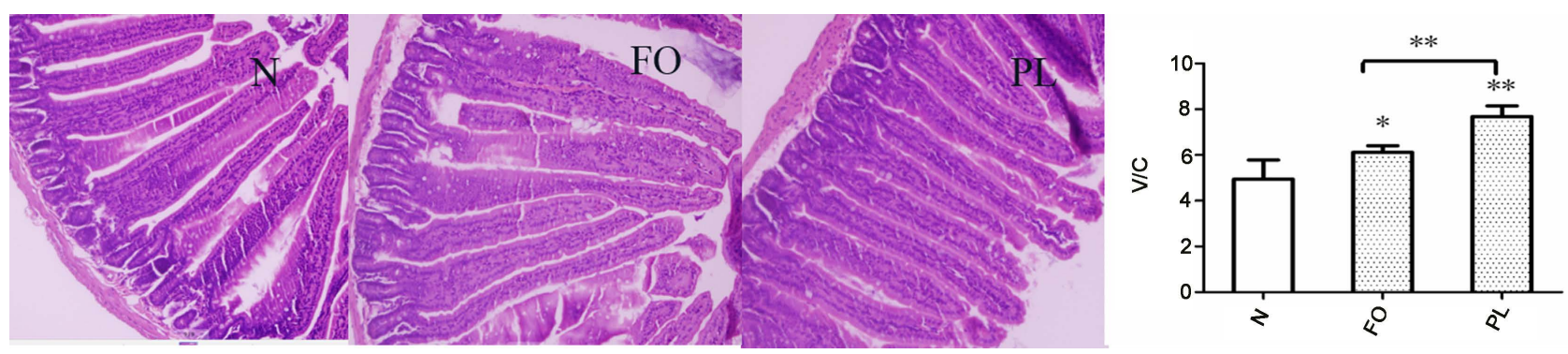

Figure 4. Changes in the morphology and the histology of the small intestine. The photographs are representative of 10 mice in each group. Scale bars indicate $100 \mathrm{um}$.

intestinal villi were complete. However, the histopathological features of the small intestine in the $\omega-3$ LCPUFA-treated mice were greatly improved. The length of the small intestine was increased and the V/C ratio were examined to 
evaluate the effect $\omega$-3 LCPUFA on the digestion-absorption function of the intestine. The V/C ratio was increased significantly in the $\omega-3$ LCPUFA group, but in PL group was higher than FO group. The data showed that $\omega-3$ LCPUFA can improve the integrity of the histological morphology of the intestinal mucosa.

\section{Discussion}

According to the study of the two types of $\omega-3$ LCPUFA and the results of DGGE, the diversity and structure of the gut microbiota significantly changed in FO and PL group. While the potential role of gut microbiota modulation in two types of $\omega-3$ LCPUFA amelioration is not clearly understood. In the (Figure 1(b)) that the bands 17 (Lactobacillus animalis), 23 (Akkermansia muciniphila), 24 (Ruminococcus), 27 (Lactococcus lactis) were superior in PL and FO group, which are bacterial species that include probiotic strains. So we can conclude that the two types of $\omega-3$ LCPUFA have the ability to improve Lactobacillus animalis, in previous study, which is a potent broad spectrum probiotic strain which inhibited bacterial pathogens, such as A. hydrophila, Pseudomonas aeruginosa and other food spoil pathogens. According to previous study, Lactobacillus animalis would range from preventing against human gastrointestinal bacterial pathogens [13] [14]. Akkermansia muciniphila is a mucin-degrading bacterium that resides in the mucus layer [15]. Recently some studies have demonstrated that $A$. muciniphila administration increased the intestinal levels of endocannabinoids that control inflammation, the gut barrier and gut peptide secretion [16]. Lactococcus lactis is a food-grade, Gram-positive lactic acid bacterium that is a harmless food industry bacterium, which has been used extensively for producing a variety of peptides, proteins, and oral vaccines. Oral administration of Lactococcus lactis H61 to aged SAMP6 mice was associated with reduced bone-density loss, improved gross lesion and enhanced immune responses, compared with those of controls [17]. Ruminococcus is considered a keystone species in the human gut that degrades microcrystalline cellulose efficiently and contains the genetic elements necessary for cellulosome production [18]. Bacterial pathogens, inflammation are harmful for intestinal mucosa. Intestinal mucosal is widely known to be responsible for the defence of the large expanse of mucous membranes that form a barrier between the external environment and the body's interior. As our result showed in (Figure 4), $\omega$-3 LCPUFA can improve the integrity of the histological morphology. Therefore, the increase of these bacteria may be helpful for intestinal mucosa protection. Intestinal barrier is crucial to control intestinal permeability whose increase is associated with chronic inflammatory conditions [19]. This may be indicated that the function of LCPUFA $\omega-3$ may be related to enhancing intestinal immunity.

We have described that phospholipids type $\omega-3$ LCPUFA can improve the richness of bacteria, while triglyceride type $\omega-3$ LCPUFA decrease it. The genetic diversity of the gut microbiota contributes to the overall development, provides the host with many beneficial functions and development of immune system. The 21 band (Streptococcus thermophilus) in PL group was inferior than the 
other two groups, in which can improve anti-inflammatory properties. This may be one of the reasons why Phospholipids type $\omega-3$ LCPUFA has superiority for human health than Triglyceride type $\omega-3$ LCPUFA.

\section{Conclusion}

The present study suggests that Phospholipids type $\omega-3$ LCPUFA and Triglyceride type $\omega-3$ LCPUFA could improve the structure of gut microbiota, increase the quantity of probiotic strain and regulate histological morphology of the small intestines. The two types $\omega-3$ LCPUFA have different impacts on microbiota regulating function. Phospholipids type $\omega-3$ LCPUFA is more superior than triglyceride type $\omega-3$ LCPUFA. The results might provide a new theoretical basis for explaining the functions of $\omega-3$ LCPUFA and the relationship between diet fat and gut microbiota.

\section{Acknowledgements}

This work was supported by the National Natural Science Foundation of China (Changhu Xue 31330060), the National Natural Science Foundation of China (Yuming Wang 31371757).

\section{References}

[1] Amandine, E., Clara, B., Lucie, G., Ouwerkerk, J.P., Céline, D., Bindels, L.B., et al. (2013) Cross-Talk between Akkermansia Muciniphila and Intestinal Epithelium Controls Diet-Induced Obesity. Proceedings of the National Academy of Sciences, 110, 9066-9071.

[2] Calder, P.C. (2015) Polyunsaturated Fatty Acids and Inflammation. Prostaglandins Leukotrienes \& Essential Fatty Acids, 67, 659-667.

[3] Carlotta, D.F., Duccio, C., Monica, D.P., Matteo, R., Jean Baptiste, P., Sebastien, M., et al. (2011) Impact of Diet in Shaping Gut Microbiota Revealed by a Comparative Study in Children from Europe and Rural Africa. Proceedings of the National Academy of Sciences, 43, S445-S446.

[4] Carmen, S.D., Miyoshi, A., Azevedo, V., Leblanc, A.D.M.D. and Leblanc, J.G. (2015) Evaluation of a Streptococcus Thermophilus Strain with Innate Anti-Inflammatory Properties as a Vehicle for il-10 Cdna Delivery in an Acute Colitis Model. Cytokine, 73, 177-183. https://doi.org/10.1016/j.cyto.2015.02.020

[5] Hiromi, K.N., Chise, S., Miho, K., Keisuke, S., Jun-Ichi, K. and Koko, M. (2007) Anti-Ageing Effect of a Lactococcal Strain: Analysis Using Senescence-Accelerated Mice. British Journal of Nutrition, 98, 1178-1186.

[6] Kim, H.B. and Isaacson, R.E. (2015) The Pig Gut Microbial Diversity: Understanding the Pig Gut Microbial Ecology through the Next Generation High Throughput Sequencing. Veterinary Microbiology, 177, 242-251.

https://doi.org/10.1016/j.vetmic.2015.03.014

[7] Laure, G., Cécile, V., Corinne, L.P., Valérie, S., Stéphanie, L.P., Jocelyne, D., et al. (2011) 13c Tracer Recovery in Human Stools after Digestion of a Fat-Rich Meal Labelled with [1,1,1-13c3]Tripalmitin and [1,1,1-13c3]Triolein. Rapid Communications in Mass Spectrometry Rcm, 25, 2697-2703. https://doi.org/10.1002/rcm.5067

[8] Lederberg, J. (2000) Infectious History. Science, 288, 287-293. 
https://doi.org/10.1126/science.288.5464.287

[9] Martin, R., Zuzana Macek, J., Ondrej, K., Tomas, J., Dasa, M., Barbora, S., et al. (2012) Metabolic Effects of n-3 Pufa as Phospholipids Are Superior to Triglycerides in Mice Fed a High-Fat Diet: Possible Role of Endocannabinoids. PLoS One, 7, e38834. https://doi.org/10.1371/journal.pone.0038834

[10] Moraï, S., David, Y.B., Bensoussan, L., Duncan, S.H., Koropatkin, N.M., Martens, E.C., Flint, H.J. and Bayer, E.A. (2016) Enzymatic Profiling of Cellulosomal Enzymes from the Human Gut Bacterium, Ruminococcus champanellensis, Reveals a Fine-Tuned System for Cohesin-Dockerin Recognition. Environmental Microbiology, 18, 542-546. https://doi.org/10.1111/1462-2920.13047

[11] Russell, W.R., Lorraine, S., Andrew, C., Richardson, A.J., Stewart, C.S., Duncan, S.H., et al. (2008) Anti-Inflammatory Implications of the Microbial Transformation of Dietary Phenolic Compounds. Nutrition \& Cancer, 60, 636-642.

https://doi.org/10.1080/01635580801987498

[12] Russell, W.R., Gratz, S.W., Duncan, S.H., Grietje, H., Jennifer, I., Lorraine, S., et al. (2011) High-Protein, Reduced-Carbohydrate Weight-Loss Diets Promote Metabolite Profiles Likely to Be Detrimental to Colonic Health. American Journal of Clinical Nutrition, 93, 1062-1072. https://doi.org/10.3945/ajcn.110.002188

[13] Sahoo, T.K., Jena, P.K., Patel, A.K. and Seshadri, S. (2015) Purification and Molecular Characterization of the Novel Highly Potent Bacteriocin tsu4 Produced by Lactobacillus animalis tsu4. Applied Biochemistry \& Biotechnology, 177, 90-104. https://doi.org/10.1007/s12010-015-1730-Z

[14] Sahoo, T.K., Jena, P.K., Nagar, N., Patel, A.K. and Seshadri, S. (2015) In Vitro Evaluation of Probiotic Properties of Lactic Acid Bacteria from the Gut of Labeo rohita and Catla catla. Probiotics and Antimicrobial Proteins, 7, 126-136. https://doi.org/10.1007/s12602-015-9184-8

[15] Simopoulos, A.P. (2008) The Importance of the Omega-6/Omega-3 Fatty Acid Ratio in Cardiovascular Disease and Other Chronic Diseases. Experimental Biology \& Medicine, 233, 674-688. https://doi.org/10.3181/0711-MR-311

[16] Santis, S.D., Cavalcanti, E., Mastronardi, M., Jirillo, E. and Chieppa, M. (2015) Nutritional Keys for Intestinal Barrier Modulation. Frontiers in Immunology, 6, 612.

[17] Tremaroli, V. and Bäckhed, F. (2012) Functional Interactions between the Gut Microbiota and Host Metabolism. Nature, 489, 242-249. https://doi.org/10.1038/nature11552

[18] Valenzuela, R., Espinosa, A., González-Mañán, D., D’Espessailles, A., Fernández, V., Videla, L.A., et al. (2012) Effect of n-3 Long-Chain Polyunsaturated Fatty Acid Supplementation of Significantly Reduces Liver Oxidative Stress in High Fat Induced Steatosis. PLoS ONE, 7, 440-440. https://doi.org/10.1371/journal.pone.0046400

[19] Van, D.E.L., Garssen, J. and Willemsen, L. (2012) Long Chain n-3 Polyunsaturated Fatty Acids in the Prevention of Allergic and Cardiovascular Disease. Current Pharmaceutical Design, 18, 2375-2392.

https://doi.org/10.2174/138161212800165960 
Submit or recommend next manuscript to SCIRP and we will provide best service for you:

Accepting pre-submission inquiries through Email, Facebook, LinkedIn, Twitter, etc. A wide selection of journals (inclusive of 9 subjects, more than 200 journals)

Providing 24-hour high-quality service

User-friendly online submission system

Fair and swift peer-review system

Efficient typesetting and proofreading procedure

Display of the result of downloads and visits, as well as the number of cited articles Maximum dissemination of your research work

Submit your manuscript at: http://papersubmission.scirp.org/

Or contact jbm@scirp.org 